\title{
Complement factor B deficiency associated with recurrent asceptic meningitis
}

\author{
J Dehoorne*, F Haerynck, A Raes, A De Guchtenaere, R Joos and J \\ Vande Walle
}

Address: Pediatric Rheumatology, University Hospital, Gent, Belgium

* Corresponding author

\author{
from $15^{\text {th }}$ Paediatric Rheumatology European Society (PreS) Congress \\ London, UK. 14-17 September 2008 \\ Published: 15 September 2008 \\ Pediatric Rheumatology 2008, 6(SuppI I):P266 doi:10.1 186/I546-0096-6-SI-P266
}

This abstract is available from: http://www.ped-rheum.com/content/6/SI/P266

(c) 2008 Dehoorne et al; licensee BioMed Central Ltd.

\section{Background}

We report complement factor B deficiency in a 16-y-old Caucasian girl, who presented with recurrent episodes of aseptic meningitis. She presented with a 2-week history of headache, vomiting, neck stiffness, facial palsy, equilibrium problems, diplopia, and low grade temperature. 4 months prior to admission she presented with a leucocytoclastic vasculitis. MRI of the brain revealed globally abnormal signal intensity in the cerebral cortex of cerebrum and cerebellum. CSF WCC was $81 / \mu \mathrm{L}$, without rise in glucose and proteins. The patient was successfully treated with high dose glucocorticoids, but tapering of dose was followed by recurrence of the symptoms. Clinical remission was achieved with plasmapheresis, corticosteroids and mofetil mycophenolate.

\section{Methods}

A moderately low C3 level $(57 \mathrm{mg} / \mathrm{dl})$ together with the clinical picture suggested a deficiency affecting regulation of complement activation

\section{Results}

Analysis of haemolytic activity revealed absence of alternative pathway activity with very low level of factor B (1 $\mathrm{mg} / \mathrm{dl}$ ) together with a low level of mannose binding protein $(199 \mathrm{ng} / \mathrm{ml})$. Levels of factor $\mathrm{H}(46 \mathrm{mg} / \mathrm{dl})$ and I (5.5 $\mathrm{mg} / \mathrm{dl}$ ) were normal.

\section{Conclusion}

Complement factor B plays an important role in the alternative complement activation pathway by complexing with $\mathrm{C} 3 \mathrm{~b}$ to create the active $\mathrm{C} 3$ convertase. Patients with abnormal levels of mannose-binding protein are known to have recurrent significant infections in the absence of abnormalities in the four major arms of the immune system. To our knowledge this is the first case of combined mannose lectin pathway and factor B deficiency. 